\title{
NON ... DELINQUERE EUM, QUI IN DUBIIS QUAESTIONIBUS CONTRA FISCUM ... RESPONDERIT. ABOUT FREEDOM OF SPEECH OF LAWYERS
}

\begin{abstract}
The subject of this study is the analysis of the text of Modestinus D. 49.14.10. This is an excerpt rarely interpreted by Romanists. The aim of this analysis is to show its significance for the author, Justinian compilers and contemporary romanists. The implementation of this goal is achieved through the application of the legal-historical and dogmatic analysis of this text. The most important, however, is the analysis of the original location by Modestyn. This will allow showing the meaning that the author gave him. The result of these interpretive procedures is the demonstration that it was a text guaranteeing the freedom of oral and written expression of advocates or trial lawyers in the judicial proceeding against the tax office. Thus, the fragment of Modestinus became an archetype of modern lawyer's immunity, consisting in the possibility of free discussion and argumentation during court hearings and in legal opinions.
\end{abstract}

KEYWORDs: tax law, in dubio pro tributario, Roman law, ius commune, state empire, interpretation of law, freedom of speech of lawyers.

\section{THE CHARACTERISTICS OF THE STATE TREASURY IN ANCIENT ROME}

The tax system in ancient Rome was quite strongly enlarged at the end of the republic (Fernández de Buján, 209, p. 1-32; Pikulska-Radomska, 2013, p. 101-105; Świrgoń-Skok, 2010, p. 243-253; Tarwacka, 2010, p. 173-185; Kuryłowicz, 2005, p. 217-223; Hopkins, 2000, p. 253-267). This is confirmed 
by numerous normative acts passed by people's assemblies (comitia), senate (senatus consulta) and, in principate, by emperor's constitution (Cvet. Calig. 40; Plin. Paneg. 37; Kamiennik, 1971, p. 9-38). The tax system was also encapsulated in studies by prudentes. Despite, the extensive legislation and doctrine under Roman law, an independent branch of financial law has not been developed.

From the analysis of sources, it appears that the various public contributions were essentially divided into vectigal (D. 50.16.17.1: "Publica" vectigalia intellegere debemus, ex quibus vectigal fiscus capit: quale est vectigal portus vel venalium rerum, item salinarum et metallorum et picariarum.) and tribute. Originally, the concept of tributa was related to the occasional public tribute imposed by the senate on the need e.g. war. After $167 \mathrm{BC}$, this term meant certain public contributions paid by the province, e.g. tributum capitis or salt tributum, taxes on the basis of the census. It should be noted, however, that these terms were often used interchangeably.

An apparatus for collecting and enforcing tax receivables was built to support the collection of public tributes. Over time, it underwent numerous transformations. The most important of them includes the transformation of the state treasury from aerarium (Agudo Ruiz, 2016, p. 158-159) to fiscus (Alpers, 1995; Brunt, 1966, p. 75-91; Millar, 1963, p. 29-42), which happened with the change of the political system from the republican to the principate. This change was caused by the departure from the concept of a state identified with the Roman nation (populus Romanus) for a state based on the ruling one.

Originally, fiscus was a private property of the emperor. However, with the increase of its omnipotence, this property became public. The components of the fiscus understood in this way were referred to as res in patrimonio fisci, it means, there were things that are money and valuable items at the disposal of the emperor, not the Roman people. This, moreover, became a multicultural nation, for which the bond was no longer the senate or the previous ius Quiritum, but the emperor's person (Agudo Ruiz, 2006, p. 161).

From the constitutional point of view, it was important, however, that the goods in the possession of the emperor began to be perceived as private property. This meant that similar rules could be applied to it as in the case of 
other private properties. Although, we cannot forget about many privileges enjoyed by fiscus (Lenz, 1994).

The new treasury of the state had not only a system of prosecution and enforcement of public charges, but also protection of its interests, analogous to the protection of property interests of other private entities. For this purpose, procurator was appointed, and then advocatus fisci, - a lawyer, an advocate, whose task was to perform the function of a fiscal trial deputy in fiscal disputes with private persons (Agudo Ruiz, 2006, p. 11).

The need to protect the interests of the tax authorities against claims of private persons - contra fiscum - is shown by many preserved sources of law (D. 49.5.6) but also by literary sources (Plin. Paneg. 37).

\section{Arguments from the LOCATION OF FRAGMENT D. 49.14.10}

The adoption of the state treasury construction as a kind of legal entity gave the private person the possibility of having litigation before courts in tax matters. The opinions of lawyers, also the advocates played and are playing till now an important role in these disputes. Such opinions in favor of the client, and contrary to the interests of the ruler, could be assessed negatively by imperial officials. It is possible that they could even meet with negative retaliation. In this perspective, the text written by the late classical lawyer - Modestinus should also perceive. This passage is basically overlooked by Romanist literature (Lenz, 1994).

D. 49.14.10 (Modest. 1. sing. de praescriptionibus): Non puto delinquere eum, qui in dubiis quaestionibus contra fiscum facile responderit.

This text was already the subject of my previous study from 2015 (Sitek, 2015, p. 55-62), which was aimed at solving other issues. Currently, the aim of the analysis of the text of Modestinus is to show its original meaning. To achieve this goal, a legal-dogmatic and a legal-historical-comparative analysis will be used.

The text itself is rather laconic, which is why it is not clearly understood after the first, cursory reading. Hence, the dogmatic analysis of this text requires first to clarify its initial location, it means, we need to carry out the arguments from the collocation. Then, a linguistic interpretation will be needed, it means, an explanation of the terminology appearing in this 
passage. In the end, thanks to the system and functional interpretation, it will be possible to finally explain the content and functions of this text.

The passage D. 49.14 .10 comes from a monograph entitled On procedural pleadings. From Palingenesi iuris civilis vol. $1 \mathrm{O}$ Lenel, it appears that only four fragments from this work have survived and they are rather loosely connected with each other. One cannot even say that their common denominator is the issue of procedural charges. Only the first of these passages (D. 5.2.12) expressly refer to the allegations regarding the raising of querella inoficiosi tetstamenti. The second fragment (D. 49.1.20) contains substantive (pr.) and procedural provisions (1-2) regarding appeals against a court decision. The third fragment (D. 50.16.106) concerns the letters of reference (dimissoriae litterae). In the end, there is the most interesting text for us, in which there is also no reference to the procedural charges.

The above analysis of the content of the preserved fragments of a monograph by Modestinus entitled Libro singulari de praescriptionibus allows us to state that the compilers retained only those fragments that were useful for them for the argumentation of other procedural and substantive matters, rather unrelated to the issue of procedural charges. However, removing those fragments from the original context deprived them of their original meaning. It is also difficult to say whether the current wording of D. 49.14.10 is original or whether it has been worked for the needs of the concept of material arrangement in book 49 under the title 14 .

\section{ANAlysis of THE PARTicular CASE}

The answers to the problem posed in the previous sentence should be sought from the texts preceding the subject fragment. It is interesting that the earlier two fragments, i.e. D. 49.14 .8 and 9 are also written by Modestinus. The first of them comes from the work entitled Libro quinto regularum $\left(5^{\text {th }}\right.$ book - law rule: Bonorum fisco vindicatorum actores venundari a procuratoribus non possunt, et, si distrahantur, irritam fieri venditionem rescriptum est.). The second comes from the libro septimo decimo responsorum, which is from the $17^{\text {th }}$ book - legal responses. The closer relationship is between fragment D. 49.14.10 and the text immediately preceding it.

D. 49.14.9 (Modest. 1. 17 resp.): Lucius Titius fecit heredes sororem suam ex dodrante, uxorem Maeviam et socerum ex reliquis portionibus: eius 
testamentum postumo nato ruptum est, qui postumus brevi et ipse decessit, atque ita omnis hereditas ad matrem postumi devoluta est. Soror testatoris Maeviam veneficii in Lucium Titium accusavit: cum non optinuisset, provocavit: interea decessit rea: nihilo minus tamen apostoli redditi sunt. Quaero, an putes extincta rea cognitionem appellationis inducendam propter hereditatem quaesitam. Modestinus respondit morte reae crimine extincto persecutionem eorum, quae scelere adquisita probari possunt, fisco competere posse.

The subject of the above passage is a dispute over who is to receive inheritance after Lucius Titus. Titus wrote down in the testament all property to his sister, his wife - Maevia's and to his father-in-law. The size of the shares in this case does not matter. The testament was overthrown as a result of the birth of a posthumous child who died shortly thereafter. As a result, his wife Maevia inherited all of Tytus' estate. The dispute about the inheritance started when the sister of the deceased accused the widow of poisoning her son, which, however, she did not prove in the first instance. Consequently, the sister of the deceased Titus appealed. However, before the decision was settled, the accused person died. Thus, a procedural problem arose, namely - whether the appeal proceedings should go on?

Modestinus proposed a decision according to which, after the death of the accused person, it is no longer possible to speak about a crime, and thus it is unfounded to continue the appeal proceedings. However, the death of the accused person did not lead to the abrogation of the suspicion of a crime, as a result of which Maevia could take over the inheritance. Under the Roman law, no one could benefit from a crime. In this case, the benefit was ex lege to the tax office. Hence, according to Modestinus, it was necessary to conduct proceedings not against, but in the case, to determine whether a crime had occurred. A positive outcome would result in the transferring of the inheritance to the tax office.

\section{The Role of ADVocate in CASES Against THE TAX OFFICE}

The analysis of the fragment D. 49.14 .9 somehow justifies the placement by the compilers of the next text written by Modestinus D. 49.14.10. This relationship should be seen in the fact that the legal problem in the dispute 
with the tax authorities was based on the help of a lawyer who issued a legal opinion in this matter. This opinion was probably unfavorable for the tax office. The aim of such an editorial procedure carried out by the compilers was to exclude the possible liability of the lawyer for unfavorable opinions of the tax office. Moreover, the lawyer's opinion was not a decision, but an accepted line of defense. The resolution of the dispute should be the result of the whole proceeding in this case, as a result of which it could turn out that no crime has been committed or that the crime cannot be proved. If that happened, then the inheritance after Tytus would be transferred to the heirs of Maevia. According to Modestinus, this legal opinion, unfavorable for the tax authorities, could not constitute an attitude to accuse the lawyer of acting contrary to the interests of the tax office.

There is no doubt, therefore, that the purpose of this brief passage of D. 49.14.10 was to release the lawyer from responsibility for providing legal opinion against or ambiguously coincident with the interests of the tax office. So, using the modern concepts, Modestinus initiated the concept of freedom of speech by a lawyer.

A further deepening of the analysis of Modestinus D. 49.14.10 requires analysis of the translation of this fragment into contemporary languages, especially English language. The particular attention should be given to explain the meaning of the three terms: delinquere, contra fiscum and facile.

According to S.P. Scott, this text should be translated into English in the following way: I do not think that he violates his duty who, in questions which are doubtful, readily answers against the Treasury, it means that the interpretation of the tax obligation against the tax office does not constitute a violation of obligations. The verb delinquere essentially means: to commit a crime, to sin, to make the mistake (Heumann, Seckel, 1958, p. 128). Modestinus's passage is therefore a clear statement that the offense is not committed by anyone who interprets the tax law against the interests of the tax office. In the same way, the Digest is translated into Polish language.

The term contra fiscum, used by Modestinus in D. 49.14.10, should be understood literally, that is against the interests of the tax office. The confirmation of this interpretation can be found in the Constitutio Antoniniana (Edict of Caracalla) which is mentioned below. 
C. 10.9.1: Imperator Antoninus . Causas, in quibus contra fiscum iudicatum est, intra triennium retractari posse, et post id tempus, si praevaricatio arguatur vel manifesta fraus probetur, notum est. ${ }^{\star}$ ANT. A. ARISTAEO. ${ }^{*}<$ A 212 PP.NON.IUL. DUOBUS ASPRIS CONSS.>

In the constitution from the year 212, thus coming more or less from the same period as the subject text of Modestinus, it was decided that in cases where the sentences unfavorable to the tax office were passed, they could be resumed within three years. The exception to this rule was the issuance of a ruling against the tax office as a result of collusion between parties (praevaricatio), for example, a deputy taxpayer and the state treasury (advocatus fisci) (Sitek, 2009), or as a result of abuse of law (D. 1.3.30: Fraus enim legi fit, ubi quod fieri noluit, fieri autem non vetuit, id fit: et quod distat hryton apo dianoias, hoc distat fraus ab eo, quod contra legem fit. See Behrends, 1982). In such cases, there was no time limit to resume the proceedings.

The Constitutio Antoniniana allows looking at D. 49.14.10 through the prism of the procedure used in cases where one of the parties was the tax office represented by advacatus fisci.

D. 49.14 .7 (Ulp. 54 ad ed.): Si fiscus alicui status controversiam faciat, fisci advocatus adesse debet. Quare si sine fisci advocato pronuntiatum sit, divus Marcus rescripsit nihil esse actum et ideo ex integro cognosci oportere.

The other party could also use a trial lawyer, an advocate who had to establish a defense line for his client's needs, undoubtedly contrary to the interests of the tax office. Modestinus in his statement preserved in D. 49.14.10 stated that the defender, in preparing the argumentation in favor of his client, de facto formulated it in contradiction with the interests of the tax office (contra fiscum).

Such a conclusion of Modestinus was extremely important for lawyers' practice in disputes with tax authorities. The position of the state or the emperor was very strong. As it is in the described event from the reign of Caligula (Svet. Calig. 40), it must have been risky to formulate a legal opinion contrary to the interests of the tax office.

This explains the meaning and role of the third term, significant for the passage D. 49.14 .10 - the term: facile. Forming an opinion by a lawyer from 
the counter-party to the tax office had to be logical, but also easy, based on the interpellation of facts in such a way that the whole thing looked good to his client.

Confirmation of the above course of argument can be found in the text of Ulpius Marcellus, a lawyer living in the second century after Christ (Kunkel, 2001, p. 213).

D. 50.17.192.1 (Marcellus 29 dig.): In re dubia benigniorem interpretationem sequi non minus iustius est quam tutius.

According to Marcellus in doubtful situations, relying on a more favorable interpretation of the factual or legal status, is not so much just, but rather safe (Palmirski, 2007, p. 309). J.A. Crook's states that the duty of an attorney in ancient Rome was to use such arguments to ensure the winnings of his client in the process (Crook, 1995; D. 50.17 .141 pr.: Quod contra rationem iuris receptum est, non est producendum ad consequentia.)

\section{The FUTURE OF THE MOdESTINUS TEXT FROM THE MIDDLE AgES TO THE TWENTIETH CENTURY}

The passage of Modestinus D. 49.14.10, not only in Roman law, was considered as an extraordinary rule. The rule in dubio contra fiscum resulting from the text of Modestinus was contrasted with the rule in dubio pro fisco rule. Due to the strong interest of the rulers, it was not widely used in ancient Rome, and it was almost completely incomprehensible in Middle Ages law.

According to M. Gregga, the rule in dubio contra fiscum was marginalized by speakers and commentators. Accursius argued that the right or interest of the tax office is always stronger - forte est ratio quia (fiscus) dives est. Besides, the very tax system in the Middle Ages was quite complicated. The interpretation of the law was narrow and literal. It was a rule generally applicable in ius commune. This does not mean that at that time, there were no ways to avoid paying taxes. Bartolus de Saxoferato described the case of avoiding the place tax from merchants selling goods on the market. The merchants of skins and sheepskin wanted to avoid paying the tax. Therefore, their goods they wore on their shoulders. They have just referred to the strict interpretation of the law. It was not possible, therefore, to enforce from them the tax payment for using the place (Greggi, 2008, p. 26-27). 
The exact translation and interpretation of the law was also adopted in the Napoleonic Code (Szczerbowski, 2014, p. 43-50; Ciućkowska 2017, p. 139-149; Mańko, 2017, p. 207-234). The change in the interpellation of tax law regulations took place only in the 20th century. This was evidenced by the jurisprudence of courts of individual European countries. In the end, the civil rights were guaranteed in the constitutional provisions, which balanced the unquestionable strong position of the state and its apparatus. Balancing of the interests of private citizens and the state in the public tributes was also based on Council Directive 1990/434 / EEC. The provisions of this directive also contain guidelines on combating tax avoidance within the European Union (OJ L 225, 20/08/1990 P. 0001 - 0005; Lázaro Guillamón 2017, p. 269-279).

\section{IN DUBIO PRO TRUBUTARIO A AND THE LAWYER'S IMMUNity IN POLISh LAW}

In the Act of $29^{\text {th }}$ August 1997 on the Tax Ordinance (Journal of Laws of 2017, item 201), the Polish legislator decided that irrelevant doubts as to the content of tax law provisions are settled in favor of the taxpayer. The rule in dubio pro tributario as a legal provision has been in force in the Polish legal system since 1 January 2016. This rule, however, already functioned in Polish law as a rule of tax law in doctrine and case law. It has its source in the content of the article 2, the article 84, and the article 217 of the Constitution of the Republic of Poland. This rule applies when the tax law provisions are unclear. Therefore, the taxpayer's interpretation is considered to be correct, as long as the administrative court or another competent authority does not state something else. Thus, the issue of an opinion by a lawyer or a tax advisor against the interest of the Treasury cannot be recognized by tax authorities or administrative courts as a crime or as an offense to the profession's dignity (Dzwonkowski, 2018, Legalis).

Finally, it should be added that in the literature, however, one can also see an opinion that the principle in dubio pro tributario is not practically applied in practice, especially in the practice of administrative courts. These courts, despite allegations raised by taxpayers and their deputies, consider that the provisions of law are unambiguous and do not raise any interpretation doubts (Dzwonkowski, 2018, Legalis). 
Issuing a legal opinion, writing pleadings or statements during a case involving the tax office cannot give rise to the liability of a lawyer, even if his or her statements are against the state. Based on the article 8 passage 1 of the Act of $28^{\text {th }}$ may 1982 on the advocacy (Journal of Laws of 2017, item 2368), the advocate, while exercising the advocacy profession, uses the freedom of speech and writing within the limits set by the advocacy duties and legal provisions (The article 11, passage 1 of the Act of 6th July 1982 on Legal Counsel (consolidated text - Journal of Laws of 2017, item 1870) and the article 37a, passage 1 of the Act of $5^{\text {th }}$ July 1996 on tax advisory services (consolidated text - Journal of Laws of 2018, pos. 377). This is professional immunity. Only abuse of this freedom may be punished.

\section{Conclusion}

An undoubted success of the Romans was the development of the concept of the tax office as an entity subject to the rules of private law. And although in Rome itself, and then in the Middle Ages, up to the twentieth century, this concept was implemented differently, it in the modern era, it plays an important role in the process of protecting the rights of the individual towards a state with specialized office apparatus. As a result, it became possible to settle fiscal disputes before common courts.

In the principate, in the fiscal disputes, the parties could have appeared with the help of the legal representatives - it means with the help of the advocates. On the side of the tax office, from the second century, advocatus fisci was obligatory. But on the other side could also be an attorney who, for the needs of the proceedings, formulated opinions that were often contrary to the interests of the tax office. The fragment of Modestinus D. 49.14.10 is an expression of contemporary freedom of speech and writing - it means, the lawyer's, legal adviser's or tax adviser's immunity. It is the oldest known text guaranteeing the release of a lawyer from responsibility for written or spoken words during fiscal processes. 


\section{References:}

Agudo Ruiz, A. (2006). El advocatus fisci en derecho romano, Dykinson, Madrid. ISBN 8497729218.

Agudo Ruiz, A. (2016). Estudios de Derecho Fiscal Romano, Dykinson, Madrid 2016. ISBN 9788490857441.

Alpers, M. (1995). Das Nachrepublikanische Finanzsystem. Fiscus und fisci in der Frühen Kaiserzeit, De Gruyter, Berlin-New York 1995. ISBN 9788490857151.

Behrends, O. (1982). Die fraus legis: zum Gegensatz von Wortlaut-und Sinngeltung in der römischen Gesetzesinterpretation, Schwartz, Gottingen 1982. ISBN 9783509012897.

Brunt, P.A. (1966). The Fiscus and its Development, The Journal of Roman Studies 56, pp. 75-91. ISSN 1753-528X.

Millar, F. (1963). The fiscus in the first two centuries, The Journal of Roman Studies 53, pp. 29-42. ISSN 1753-528X.

Ciućkowska, K. (2017). Dochodzenie roszczeń wynikających z przewlekle prowadzonego postępowania sadowego, Zeszyty Naukowe KUL 60, no 3, pp. 139-149. ISSN 0044-4405.

Crook, J.A. (1995). Legal Advocacy in the Roman World, Duckworth, London. ISBN 0715626507.

Dzwonkowski, H. (2018). Ordynacja podatkowa. Komentarz, C.H. Beck Warszawa 2018. Legalis. ISBN 9788381280006.

Fernández de Buján, A. (2009). Ius fiscale: instrumentos de política financiera $y$ principios informadores del sistema tributario romano, Revista de derecho UNED no 5, pp 185-210. ISSN 1886-9912.

Greggi, M. (2008). Avoidance and abus de droit: The European Approach in Tax Law, eJournal of Tax Research 6, no. 1, pp. 23-44. ISSN 1448-2398.

Heumann, H.G. Seckel, E. (1958). Handlexikon zu den Quellen des römischen Rechts, Akademische Druck- u. Verlagsanstalt, Graz.

Hopkins, K. (2000). Rents, Taxes, Trade and the City of Rome, In: E. Lo Cascio, In Mercati permanenti e mercati periodici nel mondo romano. Atti degli Incontri capresi di storia dell'economia antica (Capri 13-15 ottobre 1997), Edipuglia, Bari, pp 253-267. ISBN 8872282462.

Kamiennik, R. (1971). Ucisk podatkowy i nadużycia ze strony administracji rzymskiej w ostatnich wiekach cesarstwa, Rocznik Lubelski 14, pp 9-38. ISSN 0080-3510.

Kunkel, W. (2001). Die römischen Juristen. Herkunft und soziale Stellung, Bohlau Verlag, Köln, Weimar, Wien. ISBN 9783412150006. 
Kuryłowicz, M. (2005). Vicesima Hereditatum: Z historii podatku od spadków, In: $W$ kręgu prawa podatkowego i finansów publicznych: Księga dedykowana Profesorowi Cezaremu Kosikowskiemu w 40-lecie pracy naukowej, UMCS, Lublin, pp 217-223. ISBN 8322723555.

Lázaro Guillamón, M.C. (2017). Mediación policial y tutela judicial efectiva en la actualidad: reflexiones de una romanista, Zeszyty Naukowe KUL 3, pp. 269-279. ISSN 0044-4405.

Lenz, H.M. (1994). Privilegia fisci, Pfaffenweiler, Trier. ISBN

Mańko, R., (20017). Form and Substance of Legal Continuity, Zeszyty Prawnicze UKSW 17.2, pp. 207-234. ISSN 1643-8183. E-ISSN 2353-8139.

Palmirski, T. (2007). O różnych regułach dawnego prawa 17 tytuł 50 księgi Digestów tekst - tłumaczenie - komentarz, Zeszyty Prawnicze UKSW 7.2, p. 309. ISSN 1643-8183. E-ISSN 2353-8139.

Pikulska-Radomska, A. (2010). Centesima rerum venalium $i$ quinta et vicesima venalium mancipiorum: podatki od transakcji sprzedaży, In: M. Mikołajczyk et al. (ed.), O prawie i jego dziejach ksieggi dwie: Studia ofiarowane Profesorowi Adamowi Lityńskiemu w 45-lecie pracy naukowej i 70-lecie urodzin, t. I. Białystok-Katowice, pp 101-105. ISBN 9788374312264.

Pikulska-Radomska, A. (2013). Rzymskie 'tributum ex censu' jako instrument finansowy, Krytyka prawa. Niezależne studia nad prawem, 1(5), pp 504-520. ISSN 2080-1084.

Sitek, B. (2009). Crimen praevaricationis. Remarks about barristers' moral qualifications on the background of the corruptible figure of the barrister in the Ancient Rome, In: Diritto@Storia no 8 http://www.dirittoestoria.it/8/Tradizione-Romana/SitekCrimen-Praevaricationis.htm. ISSN 18250300. ISSN 1825-0300.

Sitek, B., (2015). In dubio magis contra fiscum est respondendum (D. 49.14.10), Studia Prawnoustrojowe 27, pp. 55-62. ISSN 1644-0412.

Świergoń-Skok R., (2010). Organizacja służb skarbowych $w$ sprawach podatku od spadków w państwie rzymskim, Studia Prawnoustrojowe 12, pp 243-253. ISSN 1644-0412.

Szczerbowski, J., (2014). Roman law as an instrument for promoting equality in the Napoleonic Code, Studia Prawnoustrojowen 25, pp. 43-50. ISSN 1644-0412.

Tarwacka, A. (2010). 'Incensus', czyli co groziło Rzymianom uchylającym się od płacenia podatków i służby w armii, Kwartalnik Prawa Publicznego 10.3, pp 173-185. ISSN 1642-9591. 